Article

\title{
Removal and Ecotoxicity of 2,4-D and MCPA in Microbial Cultures Enriched with Structurally-Similar Plant Secondary Metabolites
}

\author{
Elżbieta Mierzejewska ${ }^{1} \mathbb{D}$, Agnieszka Baran $^{2}$, Maciej Tankiewicz $^{3}{ }^{\mathbb{D}}$ and \\ Magdalena Urbaniak 1,4,5,* \\ 1 Department of Applied Ecology, Faculty of Biology and Environmental Protection, University of Lodz, \\ Banacha 12/16, 90-237 Lodz, Poland \\ 2 Department of Agricultural and Environmental Chemistry, Faculty of Agriculture and Economics, \\ University of Agriculture in Krakow, Mickiewicza 21, 31-120 Cracow, Poland \\ 3 Department of Environmental Toxicology, Faculty of Health Sciences, Medical University of Gdansk, \\ Dębowa 23 A, 80-204 Gdansk, Poland \\ 4 European Regional Centre for Ecohydrology of the Polish Academy of Sciences, Tylna 3, 90-364 Lodz, Poland \\ 5 Department of Biochemistry and Microbiology, Faculty of Food and Biochemical Technology, \\ University of Chemistry and Technology in Prague, Technicka 3, 16628 Prague, Czech Republic \\ * Correspondence: magdalena.urbaniak@vscht.cz
}

Received: 20 June 2019; Accepted: 8 July 2019; Published: 13 July 2019

\begin{abstract}
The removal of contaminants from the environment can be enhanced by interactions between structurally-related plant secondary metabolites (PSMs), selected xenobiotics and microorganisms. The aim of this study was to investigate the effect of selected PSMs (ferulic acid-FA; syringic acid-SA) on the removal of structurally-similar phenoxy herbicides (PHs): 2,4-dichlorophenoxyacetic acid (2,4-D) and 2-methyl-4-chlorophenoxyacetic acid (MCPA). The study also examines the biodegradation potential of soil bacteria, based on the occurrence of functional $t d f A$-like genes, and the ecotoxicity of the samples against two test species: Sinapis alba L. and Lepidium sativum L. The microbial cultures spiked with the PSMs demonstrated higher phenoxy acid removal: 97-100\% in the case of 2,4-D and 99\%-100\% for MCPA. These values ranged from 5\% to $100 \%$ for control samples not amended with FA or SA. The higher herbicide removal associated with PSM spiking can be attributed to acceleration of the microbial degradation processes. Our findings showed that the addition of SA particularly stimulated the occurrence of the total number of $t f d A$ genes, with this presence being higher than that observed in the unamended samples. PSM spiking was also found to have a beneficial effect on ecotoxicity mitigation, reflected in high (102\%) stimulation of root growth by the test species.
\end{abstract}

Keywords: 2,4-D; MCPA; plant secondary metabolites; ferulic acid; syringic acid; biodegradation; ecotoxicity

\section{Introduction}

Two of the most commonly-used herbicides in agriculture and the home/garden market sector are phenoxy herbicides (PHs), 2,4-D (2,4-dichlophenoxyacetic acid) and MCPA (2-methyl-4-chlorophenoxyacetic acid) [1]. These compounds are able to selectively control the growth of dicotyledonous weeds [2]. All PHs are constructed from ring-like structures, with at least one chlorine atom attached to the ring at different positions [3]. Their mode of action is similar to that of phytohormones (auxins), in that they disturb the physiological processes of plants and their growth regulation [4]. 
Around 6.5 million $\mathrm{kg}$ of the active ingredients of PHs (i.e., 2,4-D and MCPA) were sold in the EU in 2016, with around two million kg being sold in Poland [5]. However, such profligate usage runs the risk of misuse: incorrect storage and application practices may widen the dispersal of the compound and its metabolites throughout the environment, especially in soil and water ecosystems, thus disturbing the ecological sustainability of habitats. Environmental studies have shown the concentrations of 2,4-D and MCPA to fluctuate seasonally, e.g., from 0 to $150 \mu \mathrm{g} / \mathrm{L}$ in the Narew River (Poland) [6], and can reach a level of $329.42 \mu \mathrm{g} / \mathrm{L}$ in water coming from rice fields [7]. This is of particular concern, as EU Directive E98/83/EC specifies the maximum permissible concentration of pesticide residues in drinking water to be $0.50 \mu \mathrm{g} / \mathrm{L}$. Both 2,4-D and MCPA exhibit high toxicity to soil and water organisms, causing severe malformations and cell death $[8,9]$. The high toxicity of the PHs, together with their increasing persistence in acidic soil, creates a need to identify nature-based solutions that can enhance their degradation by autochthonous microorganisms, particularly bacteria.

One significant way of removing PHs from soil, and mitigating their toxic effects, is by the use of indigenous soil microbiota harboring desirable catabolic genes, typically those from the $t f d A$ cluster. The first step in the bacterial phenoxy herbicide degradation pathway is initiated by $\alpha$-ketoglutarate-dependent dioxygenase, which is encoded by $t f d A$ or $t f d A$-like genes $[10,11]$ such as $t f d A \alpha$ (detected in $\alpha$-Proteobacteria) and $t f d A$ Class I, II and III (identified in $\gamma$ - and $\beta$-Proteobacteria) [12]. The $t f d A$ genes encode aromatic ring hydroxylation dioxygenases (RHDO), which are widely distributed among a number of microorganisms. TfdA-like genes can also be transferred through horizontal gene transfer [12].

However, this degradation activity by indigenous soil microbiota in the environment can be restricted by unfavorable conditions, one of which being the limited availability of carbon. Hence, the biodegradative potential of soil microbiota can be increased by the addition of plant secondary metabolites (PSMs) to the soil, these being natural organic compounds frequently resembling the chemical structures of xenobiotics.

The presence of PSMs such as flavonoids, coumarins, terpenes and phenolic compounds in the soil plays an important role in the ecological relationships between plants and microorganisms. PSMs can influence the chemical and physical properties of soil, protect plants against pathogens, serve as substrates or enhance the catabolic pathway of soil microorganisms in the presence of xenobiotics [13]. They can enhance the activity of degradation processes in three key ways: by serving as primary substrates in cometabolism and providing energy for microorganism growth, by acting as inducers of degradative enzymes due to their structural similarities to xenobiotics, and by enhancing the degree of contamination removal by increasing the bioavailability of pollutants in soil [13]. The structural similarity between certain xenobiotics and PSMs may have a profound impact on the biodegradation of a given structurally-related compound (Table 1) [14,15], insofar that PH removal can be enhanced by the application of PSMs with similar chemical structures $[16,17]$.

Table 1. Examples of PSMs and Their Effect on the Biodegradation of Selected Contaminants.

\begin{tabular}{|c|c|c|c|c|}
\hline Contaminant. & Studied Plant & $\begin{array}{l}\text { Plant Secondary } \\
\text { Metabolite }\end{array}$ & Observed Effect & Literature \\
\hline Polychlorinated biphenyls (PCBs) & n.a. & flavonoid, naringin & $\begin{array}{l}\text { enhancement of PCBs reduction } \\
\text { enhancement of the }\end{array}$ & [15] \\
\hline Trichloroethene (TCE) & n.a. & cumen & $\begin{array}{l}\text { biodegradation of TCE by } \\
R \text {. gordoniae up to } 75 \% \text { within } 24 \mathrm{~h}\end{array}$ & [18] \\
\hline $\begin{array}{l}\text { Dichlorodiphenyldichloroethylene } \\
\text { (DDE) }\end{array}$ & Cucurbita pepo & $\begin{array}{l}\text { low molecular weight } \\
\text { acids (e.g., citric acid) }\end{array}$ & $\begin{array}{l}\text { enhancement of } \mathrm{p}, \mathrm{p}^{\prime} \text {-DDE } \\
\text { bioavailability in soil }\end{array}$ & [19] \\
\hline $\begin{array}{l}\text { Polycyclic aromatic hydrocarbons } \\
\text { (PAH) }\end{array}$ & Apium graveolens & linoleic acid & $\begin{array}{l}\text { enhancement of benzo }[\alpha] \text { pyrene } \\
\text { removal }\end{array}$ & [20] \\
\hline 2,4-dichlorophenol (2,4-DCP) & $\begin{array}{l}\text { soil samples taken from } \\
\text { sites located under Pinus } \\
\text { sylvestris, Quercus robur }\end{array}$ & limonene and $\alpha$-pinene & $\begin{array}{l}\text { induction of 2,4-DCP degradation } \\
\text { by indigenous soil microbiota }\end{array}$ & [21] \\
\hline
\end{tabular}


The present microcosm study examines the effect of the application of two PHs, viz. 2,4-D and MCPA, on the degradation of two structurally-similar PSMs, viz. FA and SA, to confirm whether such similarity influences the rate of removal [16]. The study examines the influence of the PSMs addition on (1) changes in $\mathrm{PH}$ concentration over time, (2) the presence of PH-degrading genes (3) and changes in ecotoxicity occurring throughout the experiment, the latter being measured using two dicotyledonous plant species: Lepidium satioum and Sinapis alba.

\section{Materials and Methods}

\subsection{Microcosm Setup}

The study was conducted in bacterial cultures containing liquid Mineral Salt Medium (MSM) $\left(1 \mathrm{~g} / \mathrm{L}\right.$ of $\mathrm{KNO}_{3}, 0.5 \mathrm{~g} / \mathrm{L}$ of $\mathrm{K}_{2} \mathrm{HPO}_{4}$ and $\mathrm{MgSO}_{4} 7 \mathrm{H}_{2} \mathrm{O}, 0.05 \mathrm{~g} / \mathrm{L}$ of $\mathrm{NaCl}$ and $\mathrm{CaCl}_{2}$, and $0.01 \mathrm{~g} / \mathrm{L}$ of $\mathrm{FeCl}_{3}$ ). MSM was filtered through a microbiological Corning ${ }^{\mathrm{TM}}$ (New York, NY, USA) Disposable Vacuum Filter $(0.22 \mu \mathrm{L})$ and enriched with soil microorganisms derived from the agricultural soil extract (SE) 50\%:50\%, v/v (see Supplementary Materials: Texts S1 and S2; Table S1).

Prepared MSM or MSM+SE samples were amended with 2,4-D ( $\geq 95.0 \%$ technical purity, molecular weight $220.04 \mathrm{~g} / \mathrm{mol}, 677 \mathrm{ppm}$ water solubility at $25^{\circ} \mathrm{C}$, pKa value 2.73, Sigma Aldrich ${ }^{\circledR}$ (St. Louis, MS, U.S.) or MCPA ( $\geq 95.0 \%$ technical purity, molecular weight $200.61 \mathrm{~g} / \mathrm{mol}, 0.825 \mathrm{~g} / \mathrm{L}$ water solubility at $20^{\circ} \mathrm{C}$, pKa value 3.07, Sigma Aldrich ${ }^{\circledR}$ (St. Louis, MS, U.S.), at doses of 0.1 and $0.5 \mathrm{mM}$.

FA ( $\geq 95.0 \%$ purity, molecular weight $194.186 \mathrm{~g} / \mathrm{mol}, 780 \mathrm{mg} / \mathrm{mL}$ water solubility at $25^{\circ} \mathrm{C}, \mathrm{pKa}$ value 4.58, Sigma Aldrich ${ }^{\circledR}$ (St. Louis, MS, U.S.), or SA ( $\geq 95.0 \%$ purity, molecular weight $198.17 \mathrm{~g} / \mathrm{mol}$, $5.78 \mathrm{mg} / \mathrm{mL}$ water solubility at $25^{\circ} \mathrm{C}$, pKa value 4.34 , Sigma Aldrich ${ }^{\circledR}$ (St. Louis, MS, U.S.) were applied at a dose of $0.25 \mathrm{mM}$ [22].

Samples containing only sterile MSM, and sterile MSM + sterile soil extract (SSE) were used as controls to assess the degree of physicochemical degradation. The samples were incubated in darkness at $25^{\circ} \mathrm{C}$ for 24 days.

\subsection{2,4-D and MCPA Concentration Measurement and Their Ppercentage Removal}

Subsamples were collected at the beginning of the experiment and after the 24-day incubation period, and these were used for monitoring changes in 2,4-D and MCPA concentration.

The concentration of 2,4-D was assessed using an enzyme immunoassay (ELISA) RaPID Assay ${ }^{\circledR}$ (A00082, Guildford, UK) 2,4-D Test Kit according to the manufacturer's instructions [23]. Each analytical batch contained a sample blank, a control sample of known concentration, four calibration standards $(0,1,10$ and $50 \mu \mathrm{g} / \mathrm{L})$ and the test samples. As the initial concentrations of 2,4-D $(0.1 \mathrm{mM}$ and $0.5 \mathrm{mM}$ ) were outside the range of the standard curve, the samples were appropriately diluted. The precision was verified by duplicate analyses, and the test reproducibility was measured using coefficients of variation (CVs); these CVs should be lower than $10 \%$ for the calibration standards, and lower than $15 \%$ for the samples. If the CVs exceeded the above values, the whole procedure was repeated to achieve good quality of the obtained results. The minimum detection level of the kit was $0.7 \mu \mathrm{g} / \mathrm{L}$. Samples showing a concentration lower than the minimum detection level were considered to be negative.

The concentration of MCPA was determined using a GC-MS TQ 8040 (Shimadzu Corp., Kyoto, Japan) gas chromatograph equipped with split/splitless injector operating in a splitless mode at $250^{\circ} \mathrm{C}$, and a triple quadrupole mass spectrometer (MS) connected to "LabSolutions" software (version 4.45, Shimadzu Corp., Kyoto, Japan) extended with Pesticide Smart Database (version 1.03, Shimadzu Corp., Kyoto, Japan) (see Supplementary Materials: Text S3).

The working standard solutions for the calibration study were prepared by spiking the tested samples with the standard solution in the concentration range of $0.01-100 \mu \mathrm{g} / \mathrm{mL}$. The linear range for MCPA was studied by replicate analysis of the standard stock solutions. The linear regression value was calculated with the mean peak areas of five replicate injections. The linear regression 
was in the range of $0.19-100 \mu \mathrm{g} / \mathrm{mL}$ with a coefficient of determination of 0.9996 . The coefficient of variability, i.e., the percentage of relative standard deviation ( $\mathrm{CV} \%)$, calculated as the mean value of the concentrations across the linear range, was found to indicate good precision (1.1\%). The sensitivity of the method was $62.5 \mathrm{ng} / \mathrm{mL}$, considered in terms of the limit of detection (LOD), calculated from calibration functions. The limit of quantization (LOQ), defined as three times the LOD value, was $0.19 \mu \mathrm{g} / \mathrm{mL}$. After the basic validation parameters had been determined, the environmental samples were analyzed in nine replications. For each sample, the mean value was calculated together with the relative standard deviation.

The percentage removal of 2,4-D and MCPA was calculated in reference to the initial concentration of herbicide used (0.1/0.5 mM). The percentage removal of studied phenoxy herbicides was calculated according to Equation (1):

$$
\mathrm{PR}=\frac{\mathrm{C}_{\mathrm{i}}-\mathrm{C}_{\mathrm{f}}}{\mathrm{C}_{\mathrm{i}}} \times 100 \%
$$

Equation (1) PR - percentage removal of phenoxy herbicides after 24 days of incubation, $C_{i}$-initial concentration of phenoxy herbicide used in the microcosm preparation; $\mathrm{C}_{\mathrm{f}}$ - final concentration of phenoxy herbicide measured after 24 days of incubation.

\subsection{Molecular Analysis}

Subsamples for molecular analysis were collected every six days, i.e., four times during the incubation period. The collected subsamples were examined for the occurrence of bacterial 16S rRNA gene fragments and five functional phenoxy acid degradative genes $(t f d A, t f d A \alpha$ and $t f d A$ Class I, $t f d A$ Class II and $t f d A$ Class III). DNA was extracted from the soil bacteria using a GeneMATRIX Soil DNA Purification Kit Eur ${ }^{\circledR}$ (Gdansk, Poland), according to the manufacturer's instructions. Polymerase Chain Reaction (PCR) conditions were applied according to literature (see Supplementary Materials: Table S2) with minor modifications of annealing temperatures. The $20 \mu \mathrm{L}$ reaction mixture contained: sterile $\mathrm{H}_{2} \mathrm{O}$, 1xbuffer, $3.5 \mathrm{mM} \mathrm{MgCl} 2,0.2 \mathrm{mM}$ dNTP, $0.5 \mu \mathrm{M}$ primers, $0.1 \mathrm{mg} / \mathrm{mL}$ BSA, $1-2.5 \mathrm{U} / \mu \mathrm{L}$ Taq Polymerase and 15-30 ng of template DNA. Five sets of $t f d A$ gene primers (see Supplementary Materials: Table S2) were used for the amplification of given bacterial DNA fragments. The conditions for the PCR were optimized for each studied gene. PCR products were checked using 1.5\% agarose gel electrophoresis and stained with ethidium bromide.

The $16 S$ rRNA gene fragments (1300-1400 bp) obtained from the variants amended with MCPA and SA were additionally amplified by PCR using thermostable Pfu DNA polymerase (ThermoScientific ${ }^{\circledR}$ (Waltham, MA, U.S.) and bacterium specific forward primer (27F5'-AGAGTTTGATCCTGGCTCAG-3') and a universal reverse primer (1492R5-GGTTACCTTGTTACGACTT-3') [24]. The amplified 16S rRNA gene fragments were purified using a QIAGEX ${ }^{\circledR}$ II Gel Extraction Kit (Qiagen) (Hilden, Germany) and subjected to sequencing. Homology searches were performed using the National Center for Biotechnology Information microbial and nucleotide BLAST network service (http://blast.ncbi.nlm.nih. gov/Blast.cgi) and Vector NTI AdvanceTM 9 software (Invitrogen) (Carlsbad, CA, USA).

\subsection{Ecotoxicity Assessment}

Ecotoxicity measurements were performed twice during the experiment: at the beginning and after a 24-day incubation period, using Phytotoxkit Test (Microbiotest Inc., Nazareth, Belgium) [25], a commercial toxicity bioassay. The test compares the degree of inhibition of root length of certain test species after three days of exposure to a control sample with that of an uncontaminated control containing only distilled water. For the purpose of this experiment, the dicotyledons Lepidium sativum (L.) and Sinapis alba (L.) were used as test plants. The samples were classified as non-toxic when the percent effect of root growth inhibition (PE\%) was $\geq 20 \%$, slightly toxic for $20 \% \leq \mathrm{PE}<50 \%$, toxic for $50 \% \leq \mathrm{PE}<100 \%$, and highly toxic for $\mathrm{PE}=100 \%$ [26]. 
The percentage effect on root growth inhibition of the studied soil was calculated according to Equation (2):

$$
\mathrm{PE}=\frac{\mathrm{A}-\mathrm{B}}{\mathrm{A}} \times 100 \%
$$

Equation (2) PE-percentage effect of root growth inhibition, A-plant root length in control soil; B-plant root length in studied soil.

\section{Results}

\subsection{Changes in 2,4-D and MCPA Concentration}

Table 2 indicates the results of 2,4-D and MCPA degradation during 24 days of incubation. Regarding the samples amended with $0.1 \mathrm{mM} 2,4-\mathrm{D}$, between $83 \%$ and $93 \%$ degradation was observed for sterile untreated controls; however, this increased to $98 \%$ in samples with soil microorganisms enriched with SE, and to $100 \%$ for samples with MSM + SE + FA. For sterile samples amended with $0.5 \mathrm{mM} 2,4-\mathrm{D}$, the samples treated with MSM + SE, MSM and MSM + FA demonstrated a removal rate of 100\%, while those treated with SSE alone demonstrated $99 \%$ removal. Those treated with FA displayed slightly lower removal (97\%).

Table 2. Percentage Removal (PR) of PH (2,4-D and MCPA) in Studied Samples.

\begin{tabular}{|c|c|c|c|}
\hline PH & Concentration (mM) & Sample * & PR \\
\hline \multirow{10}{*}{$2,4-\mathrm{D}$} & \multirow{5}{*}{0.1} & MSM & 86 \\
\hline & & MSM + FA & 93 \\
\hline & & $\mathrm{MSM}+\mathrm{FA}+\mathrm{SSE}$ & 83 \\
\hline & & $\mathrm{MSM}+\mathrm{SE}$ & 98 \\
\hline & & $\mathrm{MSM}+\mathrm{SE}+\mathrm{FA}$ & 100 \\
\hline & \multirow{5}{*}{0.5} & MSM & 100 \\
\hline & & $\mathrm{MSM}+\mathrm{FA}$ & 100 \\
\hline & & $\mathrm{MSM}+\mathrm{FA}+\mathrm{SSE}$ & 99 \\
\hline & & $\mathrm{MSM}+\mathrm{SE}$ & 100 \\
\hline & & $\mathrm{MSM}+\mathrm{SE}+\mathrm{FA}$ & 97 \\
\hline \multirow{10}{*}{ MCPA } & \multirow{5}{*}{0.1} & MSM & 40 \\
\hline & & $\mathrm{MSM}+\mathrm{SA}$ & 11 \\
\hline & & $\mathrm{MSM}+\mathrm{SA}+\mathrm{SSE}$ & 19 \\
\hline & & $\mathrm{MSM}+\mathrm{SE}$ & 53 \\
\hline & & $\mathrm{MSM}+\mathrm{SE}+\mathrm{SA}$ & 99 \\
\hline & \multirow{5}{*}{0.5} & MSM & 27 \\
\hline & & $\mathrm{MSM}+\mathrm{SA}$ & 5 \\
\hline & & $\mathrm{MSM}+\mathrm{SA}+\mathrm{SSE}$ & 12 \\
\hline & & $\mathrm{MSM}+\mathrm{SE}$ & 99 \\
\hline & & $\mathrm{MSM}+\mathrm{SE}+\mathrm{SA}$ & 100 \\
\hline
\end{tabular}

* MSM—-mineral salt medium; SSE—sterile soil extract; SE—soil extract; FA—ferulic acid; SA—syringic acid.

In contrast, lower removal rates were observed for the samples amended with $0.1 \mathrm{mM}$ MCPA: $11-40 \%$ removal was observed for the sterile, untreated samples, $53 \%$ for those treated with SE and $99 \%$ for those treated with MSM + SE + SA. Similar removal rates were observed for samples amended with $0.5 \mathrm{mM}$ MCPA: MCPA removal ranged from $5 \%$ to $27 \%$ for sterile untreated samples, which increased to $99 \%$ for the SE samples and $100 \%$ for the SE + SA.

\subsection{Molecular Analysis}

Table 3 and Figure 1 show the results of the molecular analysis for studied samples. The bacterial $16 S$ rRNA gene fragment was detected in all studied samples containing SE. In the MSM + SE variant, the $t f d A \alpha$ gene fragment was detected after 6,12 and 18 days of incubation and the $t f d A$ gene fragment after 18 and 24 days. In the samples amended with $0.1 \mathrm{mM}$ 2,4-D, the $t f d A$ Class III gene was present during the whole experiment; however, the gene detection pattern changed after the addition of FA: the $t f d A$ Class I gene was detected after 6, 12, 18 days and the $t f d A \alpha$ gene was detected after 18 and 24 days. The use of $0.5 \mathrm{mM} 2,4-\mathrm{D}$, i.e., the higher concentration, shifted the frequency and timing of gene 
fragment detection: in samples with SE, $t f d A \alpha$ was detected only once after 24 days and $t f d A$ Class III was observed after 12 and 18 days of incubation. The genes were found to be less apparent in the MSM $+\mathrm{SE}+$ FA variant (Table 4): only $t f d A$ Class I was observed, on one occasion, after 6 days, $t f d A \alpha$ was observed after 6, 18 and 24 days.

Table 3. PCR Results for Target Genes; "+"Presence of PCR Product on 1.5\% Agar Gel Electrophoresis; CI-Class I, CII-Class II, CIII-Class III.

\begin{tabular}{|c|c|c|c|c|c|c|c|c|c|c|c|c|c|c|}
\hline \multirow[b]{2}{*}{ PH } & \multicolumn{2}{|c|}{ Target Gene } & $\begin{array}{c}16 S \\
r R N A\end{array}$ & $\begin{array}{l}\text { tfdA } \\
\text { alfa }\end{array}$ & $\begin{array}{c}t f d A \\
C I\end{array}$ & $\begin{array}{c}t f d A \\
C I I\end{array}$ & $\begin{array}{l}t f d A \\
\text { CIII }\end{array}$ & $t f d A$ & $\begin{array}{l}16 S \\
\text { rRNA }\end{array}$ & $\begin{array}{l}\text { tfdA } \\
\text { alfa }\end{array}$ & $\begin{array}{c}t f d A \\
C I\end{array}$ & $\begin{array}{l}t f d A \\
C I I\end{array}$ & $\begin{array}{l}t f d A \\
C I I I\end{array}$ & $t f d A$ \\
\hline & $\begin{array}{c}\text { Days of } \\
\text { Incubation }\end{array}$ & $\begin{array}{c}\text { 2,4-D/MCPA } \\
\text { Concentration } \\
(\mathrm{mM})\end{array}$ & & & MSM & $+\mathrm{SE}$ & & & & & ISM + & $\mathrm{SE}+\mathrm{FA}$ & & \\
\hline \multirow{12}{*}{ 2,4-D } & 6 & \multirow{4}{*}{0} & + & + & & & & & + & + & + & & & \\
\hline & 12 & & + & + & & & & & + & & & & & \\
\hline & 18 & & + & + & & & & + & + & + & & & & \\
\hline & 24 & & + & & & & & + & + & + & & & & \\
\hline & 6 & \multirow{4}{*}{0.1} & + & & & & + & & + & & + & & & \\
\hline & 12 & & + & & & & + & & + & & + & & & \\
\hline & 18 & & + & & & & + & & + & + & + & & & \\
\hline & 24 & & + & & & & + & & + & + & & & & \\
\hline & 6 & \multirow{4}{*}{0.5} & + & & & & & & + & & & & & \\
\hline & 12 & & + & & & & + & & + & & + & & & \\
\hline & 18 & & + & & & & + & & + & & & & & \\
\hline & 24 & & + & + & & & & & + & & & & & \\
\hline & & & \multicolumn{6}{|c|}{$\mathrm{MSM}+\mathrm{SE}$} & \multicolumn{6}{|c|}{$\mathrm{MSM}+\mathrm{SE}+\mathrm{SA}$} \\
\hline \multirow{12}{*}{ МСРА } & 6 & \multirow{4}{*}{0} & + & + & & & & & + & & & & & \\
\hline & 12 & & + & + & & & & & + & & & & + & \\
\hline & 18 & & + & + & & & & + & + & + & & & + & \\
\hline & 24 & & + & & & & & + & + & & & & + & \\
\hline & 6 & \multirow{4}{*}{0.1} & + & & & & & & + & + & & + & + & \\
\hline & 12 & & + & & & & & & + & & & & + & \\
\hline & 18 & & + & & & & & & + & & & & + & \\
\hline & 24 & & + & & & & & & + & & & + & & \\
\hline & 6 & \multirow{4}{*}{0.5} & + & + & & + & + & & + & & & & & \\
\hline & 12 & & + & & & & + & & + & + & + & + & & \\
\hline & 18 & & + & & & & + & & + & + & + & + & + & \\
\hline & 24 & & + & + & + & + & & & + & + & & + & + & \\
\hline
\end{tabular}

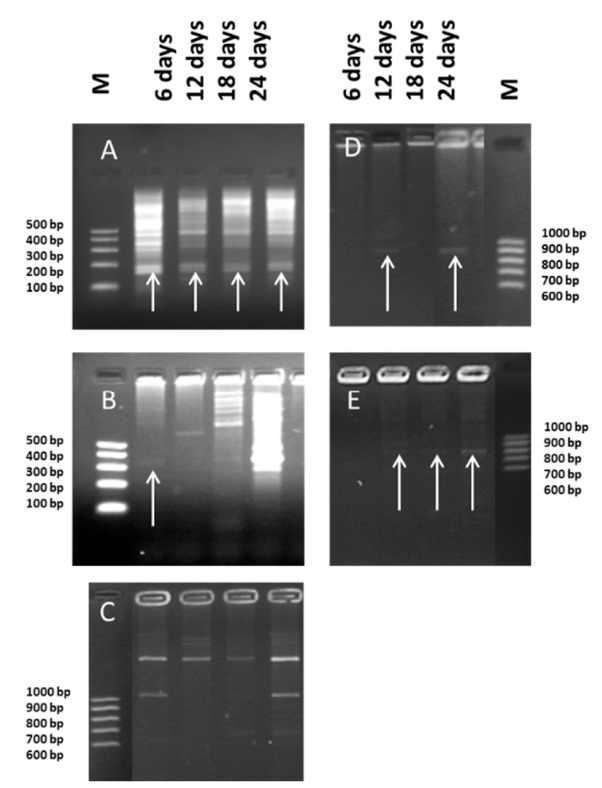

Figure 1. PCR Results Visualized on Gel Electrophoresis for Samples with MCPA (0.1 mM), SE and SA after 6, 12,18, 24 days of incubation; A-16S rRNA; B—tfdA $\alpha$; C—tfdA Class I; D—tfdA Class II; E—tfdA Class III M-marker, bp-base pairs. 
Table 4. Number of Different Functional Genes Present in Studied Samples After 6, 12, 18, 24 Days of Incubation and Total Number of Detected Functional Genes.

\begin{tabular}{|c|c|c|c|c|c|c|c|}
\hline \multirow{3}{*}{ PH } & \multirow{3}{*}{ Concentration } & \multirow{3}{*}{ Sample Variant * } & \multicolumn{5}{|c|}{$\begin{array}{l}\text { Nr of Detected } \\
\text { Functional Genes }\end{array}$} \\
\hline & & & \multicolumn{4}{|c|}{ Days of Incubation } & \multirow{2}{*}{ Total } \\
\hline & & & 6 & 12 & 18 & 24 & \\
\hline \multirow{3}{*}{ - } & \multirow{3}{*}{0} & $\mathrm{MSM}+\mathrm{SE}$ & 1 & 1 & 2 & 1 & 5 \\
\hline & & $\mathrm{MSM}+\mathrm{SE}+\mathrm{FA}$ & 2 & 0 & 1 & 1 & 3 \\
\hline & & $\mathrm{MSM}+\mathrm{SE}+\mathrm{SA}$ & 0 & 1 & 2 & 1 & 4 \\
\hline \multirow{4}{*}{$2,4-\mathrm{D}$} & \multirow{2}{*}{0.1} & $\mathrm{MSM}+\mathrm{SE}$ & 1 & 1 & 1 & 1 & 4 \\
\hline & & $\mathrm{MSM}+\mathrm{SE}+\mathrm{FA}$ & 1 & 1 & 2 & 1 & 5 \\
\hline & \multirow{2}{*}{0.5} & $\mathrm{MSM}+\mathrm{SE}$ & 0 & 1 & 1 & 1 & 3 \\
\hline & & $\mathrm{MSM}+\mathrm{SE}+\mathrm{FA}$ & 0 & 1 & 0 & 0 & 1 \\
\hline \multirow{4}{*}{ MCPA } & \multirow{2}{*}{0.1} & $\mathrm{MSM}+\mathrm{SE}$ & 0 & 0 & 0 & 0 & 0 \\
\hline & & $\mathrm{MSM}+\mathrm{SE}+\mathrm{SA}$ & 3 & 1 & 1 & 1 & 6 \\
\hline & \multirow{2}{*}{0.5} & $\mathrm{MSM}+\mathrm{SE}$ & 3 & 1 & 1 & 3 & 8 \\
\hline & & $\mathrm{MSM}+\mathrm{SE}+\mathrm{SA}$ & 0 & 3 & 4 & 3 & 10 \\
\hline
\end{tabular}

* MSM-mineral salt medium; SSE—sterile soil extract; SE—soil extract; FA—ferulic acid; SA—syringic acid.

Among the variants amended with $0.1 \mathrm{mM} \mathrm{MCPA}$, no functional genes were detected in the SE samples. However, the SA samples demonstrated $t f d A \alpha$ on day 6 of incubation, $t f d A$ Class II on day 6 and day 24, and $t f d A$ Class III on days 6, 12 and 18. In the samples with $0.5 \mathrm{mM} \mathrm{MCPA}$, all tested gene fragments were observed ( $t f d A \alpha$ after 6 and 24 days, $t f d A$ Class I after 24 days, Class II after 6 and 24 days and Class III after $6,12,18$ days). In the MSM + SE + SA variant, $t f d A \alpha$ was present after 12,18 , 24 days, $t f d A$ Class I after 12 and 18 days, $t f d A$ Class II after 12, 18 and 24 days, and $t f d A$ Class III after 18 and 24 days. In comparison to the sample amended with SE, the addition of SA was associated with a twofold increase in gene detection (Table 4). After 12 days, $t f d A$ Class III was detected throughout the whole incubation period in samples amended with MSM + SE + SA. When SA was applied, the detection of the studied genes was found to double for both the $t f d A \alpha$ and the $t f d A$ Class I genes.

In addition, most of the samples treated with $0.1 \mathrm{mM} \mathrm{MCPA}$ did not demonstrate the presence of any $t f d A$-like genes; however, $30 \%$ of the $0.1 \mathrm{mM} \mathrm{MCPA}$ samples treated with SA were found to contain three of the five tested genes: $t f d A \alpha, t f d A$ Class II and $t f d A$ Class III (Table 4). Greater detection rates were observed in the case of samples treated with $0.5 \mathrm{mM} \mathrm{MCPA}$ : the genes were detected in $45 \%$ of all samples, i.e., $40 \%$ when PSM was not added and 50\% when it was (Table 3).

Our analysis confirmed that SA spiking increased the number of detected functional genes and MCPA removal efficiency. Hence, the sample containing MCPA, SE and SA was selected for further analysis of the biodiversity of the microbial populations which were present in samples amended with herbicide and selected PSMs. Analyses of the 16S rRNA gene sequences within the samples revealed widespread enrichment of several sequence variants associated with known microbial degraders of many classes of environmental organic pollutants (Table 5). These degraders include members of the genera Rhodoferax, Achromobacter, Burkolderia and Cupriavidus (see Supplementary Materials: Figures S1 and S2).

Table 5. The Results of Sequence Alignments for Samples with MCPA, SE and SA.

\begin{tabular}{cccc}
\hline $\begin{array}{c}\text { Class of } \\
\text { Microorganisms }\end{array}$ & Identified Strain & Homology & E-value \\
\hline & Rhodoferax saidenbachensis strain OX0321 & $100 \%$ & 0 \\
Achromobacter dolens strain BFHC15 & $99 \%$ & $1.0 \times 10^{-44}$ \\
B-proteobacteria & Burkholderia sp. & $99 \%$ & $1.0 \times 10^{-44}$ \\
& strain A5 & $99 \%$ & $4.0 \times 10^{-44}$ \\
\hline
\end{tabular}




\subsection{Changes in Ecotoxicity}

Table 6 shows the results of the ecotoxicity assay based on two dicotyledonous species: L. sativum and S. alba; measurements were taken at the beginning of the experiment and after 24 days of incubation. At the beginning of the experiment, the MSM + SE sample demonstrated root growth inhibition of $51 \%$ (toxic) for L. sativum and $57 \%$ (toxic) for S. alba. All samples treated with $0.1 \mathrm{mM}$ or $0.5 \mathrm{mM} 2,4-\mathrm{D}$ displayed $100 \%$ inhibition (highly toxic) for L. sativum; however, the $0.1 \mathrm{mM} 2,4$-D samples displayed $98 \%$ inhibition (toxic) for S. alba and the $0.5 \mathrm{mM} \mathrm{2,4-D}$ samples $94 \%$ inhibition (toxic). All samples amended with MCPA (0.1 and $0.5 \mathrm{mM}$ ) demonstrated $100 \%$ (highly toxic) root growth inhibition in both studied plant species.

Table 6. Root Growth Inhibition (PE) in Samples Before and After 24 Days of Incubation.

\begin{tabular}{|c|c|c|c|c|c|c|c|c|c|c|c|}
\hline \multirow[b]{2}{*}{ PH } & \multirow[b]{2}{*}{$\begin{array}{c}\text { 2,4-D/MCPA } \\
\text { Concentration } \\
(\mathrm{mM})\end{array}$} & \multicolumn{5}{|c|}{ L. sativum } & \multicolumn{5}{|c|}{ S. alba } \\
\hline & & MSM & $\begin{array}{c}\text { MSM } \\
+ \text { PSM * }\end{array}$ & $\begin{array}{l}\text { MSM } \\
+ \text { SSE }\end{array}$ & $\begin{array}{l}\text { MSM } \\
+ \text { SE }\end{array}$ & $\begin{array}{c}\text { MSM + } \\
\text { SE+ } \\
\text { PSM * }\end{array}$ & MSM & $\begin{array}{c}\text { MSM } \\
+ \text { PSM * }\end{array}$ & $\begin{array}{l}\text { MSM } \\
+ \text { SSE }\end{array}$ & $\begin{array}{l}\text { MSM } \\
+ \text { SE }\end{array}$ & $\begin{array}{c}\text { MSM + } \\
\text { SE + } \\
\text { PSM * }\end{array}$ \\
\hline \multicolumn{12}{|c|}{ PE at the Beginning of the Experiment } \\
\hline- & - & n.a. & n.a. & n.a. & 51 & n.a. & n.a. & n.a. & n.a. & 57 & n.a. \\
\hline \multirow{2}{*}{ 2,4-D } & 0.1 & 100 & n.a. & n.a. & n.a. & n.a. & 98 & n.a. & n.a. & n.a. & n.a. \\
\hline & 0.5 & 100 & n.a. & n.a. & n.a. & n.a. & 94 & n.a. & n.a. & n.a. & n.a. \\
\hline \multirow{2}{*}{ MCPA } & 0.1 & 100 & n.a. & n.a. & n.a. & n.a. & 100 & n.a. & n.a. & n.a. & n.a. \\
\hline & 0.5 & 100 & n.a. & n.a. & n.a. & n.a. & 100 & n.a. & n.a. & n.a. & n.a. \\
\hline \multicolumn{12}{|c|}{ PE After 24 Days of Incubation } \\
\hline \multirow{2}{*}{$2,4-\mathrm{D}$} & 0.1 & 100 & 98 & 100 & 100 & 100 & 96 & 95 & 97 & 94 & 98 \\
\hline & 0.5 & 10 & 100 & 100 & 100 & 100 & 96 & 96 & 96 & 97 & 97 \\
\hline \multirow{2}{*}{ MCPA } & 0.1 & 100 & 100 & 100 & $-102 *$ & $-69 *$ & 100 & 100 & 100 & $-34 *$ & $-21 *$ \\
\hline & 0.5 & 100 & 100 & 100 & $-47^{*}$ & $-55^{*}$ & 100 & 100 & 100 & $-38^{*}$ & $-35^{*}$ \\
\hline
\end{tabular}

n.a.-not analyzed; * PSM-plant secondary metabolite (FA for 2,4-D samples and SA for MCPA-amended samples);

Negative values indicate stimulation of root growth by the test plants with regard to the control sample.

After 24 days, in sterile samples amended with $0.1 \mathrm{mM}$ 2,4-D, the ecotoxicity still remained very high. Samples treated with MSM showed 100\% growth inhibition (highly toxic) for L. sativum and 96\% (toxic) for S. alba. Likewise, MSM+FA demonstrated 98\% inhibition (toxic) for L. sativum and 95\% (toxic) for S. alba. The MSM + SSE variant demonstrated 100\% (highly toxic) inhibition for L. sativum and $97 \%$ (toxic) inhibition for S. alba.

At the higher initial concentration of 2,4-D (0.5 mM), sterile samples demonstrated $100 \%$ (highly-toxic) inhibition for L. sativum and 96\% (toxic) for S. alba. Both samples with SE and those with MSM + SE + FA displayed 100\% (highly-toxic) inhibition for L. sativum and 97\% (toxic) for S. alba.

The samples treated with MCPA also demonstrated high ecotoxicity, with the sterile samples being $100 \%$ (highly toxic) for both plants at both PH concentrations. Nevertheless, the application of soil extract ameliorated this highly toxic effect. Among the samples amended with $0.1 \mathrm{mM} \mathrm{MCPA}$, the SE samples showed a stimulation effect of $-102 \%$ (non-toxic) for L. sativum and $-34 \%$ (non-toxic) for S. alba, while the SE + SA samples demonstrated $-69 \%$ (non-toxic) for L. sativum and $-21 \%$ (non-toxic) for S. alba. For the samples dosed with $0.5 \mathrm{mM} \mathrm{MCPA}$, the PE\% values for the MSM + SE samples were $-47 \%$ (non-toxic) for L. sativum and $-38 \%$ (non-toxic) for S. alba, while those for the MSM + SE + SA samples were $-55 \%$ (non-toxic) for L. sativum and $-35 \%$ (non-toxic) and S. alba.

\section{Discussion}

To improve crop yields and mitigate the risk of economic loss caused by weeds, it is often necessary to apply herbicides, e.g., $\mathrm{PHs}$, to soil; however, inappropriate storage practices and usage can result in PHs being dispersed throughout the environment. Following dispersal, their residues can accumulate in indigenous plant and aquatic organisms, where they can adversely affect their metabolism. Although they are initially released into the environment in the form of commercial products containing phenoxy acids salts or esters, these products immediately hydrolyze to their corresponding anionic or neutral forms upon exposure to environmental conditions [27]. Residual forms of active ingredients (2,4-D, 
MCPA) can be adsorbed by soil particles and transported to terrestrial and water ecosystems (surfaceand groundwater) with runoff and in the soil profile [28]. Hence, there is a need to identify methods that enable effective elimination of these pollutants from the environment; of these, nature-based approaches offer the greatest potential, as these are cheaper and less likely to be harmful to the environment. One such approach is based on the stimulation of biodegradation: a promising, environmentally-friendly and cost-effective method of enhancing naturally-occurring processes of contaminant removal. The present study compares the potential of selected PSMs as stimulators of biodegradation of certain PHs which form the basis of widely-used herbicides: FA against 2,4-D, and SA against MCPA. The method employed a tripartite approach: phenoxy acid removal efficiency was assayed, the bacterial communities involved in the biodegradation processes were identified by bacterial gene analysis, and changes in sample ecotoxicity were determined.

\subsection{The Influence of Selected PSMs on 2,4-D/MCPA Removal}

Various PSMs appear to stimulate the biodegradation of organic pollutants in soil (Table 1). However, as the sterile samples and those amended with SE demonstrated similar efficiency in reducing 2,4-D concentration, it is possible that such degradation is driven mainly by physicochemical processes. Recent research by McMartin et al. [29] found the half-life values of 2,4-D in water samples to range between 30 and 40 hours, which is consistent with our present results obtained in sterile samples (Table 2). McMartin et al. also reported that the microorganisms required an acclimation period of 18 days before commencing the biodegradation of 2,4-D.

In contrast to our results, it has previously been suggested that samples amended with Pseudomonas cepacia populations displayed significant reductions of 2,4-D in comparison to controls, and that biodegradation of 2,4-D is determined by biotic factors [30]. McLoughlin et al. [21] also note that PSMs such as $\alpha$-pinen and limonene play a significant role in enhancing the removal of 2,4-DCP (2,4-D metabolite: 2,4-dichlorophenol) from soil matrices. Our present findings indicated that both 2,4-D and FA, and their metabolites, exerted a toxic effect on the bacterial consortia in the amended samples; hence, it is more likely that the removal of 2,4-D was mainly driven by physicochemical processes.

After 24 days of incubation, MCPA removal in the sterile variants ranged from $19 \%$ to $40 \%$ when applied at $0.1 \mathrm{mM}$, and from $5 \%$ to $27 \%$ when applied at $0.5 \mathrm{mM}$; the addition of soil microbiota enhanced the removal rate to $53 \%(0.1 \mathrm{mM})$ and $99 \%(0.5 \mathrm{mM})$. The application of both SE and SA boosted the process of MCPA removal to $99 \%$ for $0.1 \mathrm{mM}$ MCPA and to $100 \%$ for $0.5 \mathrm{mM}$ MCPA. However, regarding the soil amended with $0.5 \mathrm{mM} 2,4-\mathrm{D}$, no significant difference was observed between the sterile samples and those amended with soil extract.

These results indicated that two related compounds, in this case, 2,4-D and MCPA, can behave very differently in the presence of structurally-related PSMs: although the biodegradation of MCPA was enhanced by SA, no such effect was observed on 2,4-D by FA. Two critical factors determining the biostimulation effect of PSM appear to be the selection of structurally-related PHs and PSMs, and the initial concentration of the contaminant.

\subsection{The Influence of Selected PSMs on the Degradation Potential of SE Bacteria toward 2,4-D/MCPA}

Previous studies indicated that the biodegradation processes taking place in the rhizosphere are stimulated solely by PSMs. They can serve as cometabolites and provide the energy needed by microorganisms to carry out biodegradation processes. It is worth noting that PSMs can stimulate the expression of desirable genes present in environmental matrices if they bear a similar structural similarity to certain xenobiotics. Additionally, PSMs can be used as a primary source of carbon for bacterial communities to support their growth and increase their tolerance to higher concentrations of toxic compounds $[21,30]$. The presence of functional genes indicates that the microorganisms present in environment have the potential to degrade xenobiotics such as PHs.

$\mathrm{PH}$ degradative $t f d A$-like genes belong to the catabolic gene cluster $t f d A B C D F E$, which is thought to be widely distributed in the environment among Proteobacteria. These genes have been extensively 
studied since the early use of 2,4-D-based herbicides in the 1950s. These $t f d A$-like genes have been used as markers for the presence of 2,4-D catabolism for two key reasons: they encode the dioxygenase enzyme, which plays a critical role in the initiation of PH biodegradation, and they are characterized by a unique nucleotide sequence and function [12]. Among the 2,4-D degraders, the bacteria harboring $t f d A$-like genes can be divided into four distinct groups, according to their base nucleotide sequence. The first group, the $\alpha$-Proteobacteria, harbor the $t f d A \alpha$ gene; this group comprises bacteria closely related to Bradyrhizobium spp. [31]. The remaining three groups, harboring tfdA Class I, II and III, include various bacterial strains belonging to $\gamma$ - and $\beta$-Proteobacteria [11,32]. Class I was isolated from contaminated sites and is known to be present in $\beta$ - and $\gamma$-Proteobacteria such as Cupriavidus pinatubonensis JMP134; in contrast, $t f d A$ Class II is less widely distributed, being found in Burkholderia spp., while $t f d A$ Class III was found in Comamonas acidovorans [33]. The location of the $t f d A$ gene also differs between classes: $t f d A$ Class I and III $t f d A$ are located on self-transmissible plasmids [34], while $t f d A$ Class II genes are located on bacterial chromosomes [12].

Therefore, the presence and type of $t f d A$-like genes can be used as indicators to identify the biodegradation potential of bacteria present in studied soil. Our findings confirm the presence of bacterial DNA, including the conservative $16 S$ rRNA gene fragment, in all the samples amended with SE. PCR amplification revealed almost all selected functional gene fragments to be abundant in the studied samples; however, significant differences in gene profile were observed between samples amended with 2,4-D and MCPA at the two initial concentrations.

These functional genes were present in the sample spiked with SE (Table 3), which indicates that PH-degrading bacteria were already present in the studied soil. These results are consistent with those of our previous studies, where $t f d A$ Class III and $t f d A \alpha$ genes were detected in control soil [35]; however, although the soil extract was prepared from the same soil material as in the previous studies, only the $t f d A$ and $t f d A \alpha$ genes were detected [35]. It is important to underline that these two experiments were conducted in different media: soil and liquid MSM. The presence of functional genes suggests that the soil used for soil extract preparation might have been exposed to PHs for a longer time prior to collection. This observation is consistent with ecotoxicity results, where samples with the soil extract exhibited ecotoxicity levels as high as $57 \%$.

In samples amended with 2,4-D, the initial concentration had a significant effect on the presence of the studied genes, with $t f d A$ Class III genes being detected later at the higher dose of 2,4-D (0.5 $\mathrm{mM}$ ), which may be due to the cytotoxic action of 2,4-D. In addition, higher herbicide concentrations were associated with lower numbers of the present functional genes. Following supplementation with a selected PSM (FA), the pattern of genes in the samples changed to $t f d A$ Class I and $t f d A \alpha$, indicating that FA influenced the structure of the microbial communities. The same amplicons were detected in the sample treated with SE + FA. FA has a strong effect on the microorganisms in the local environment and their degradative activities; however, its presence does not appear to lower the ecotoxicity effect of 2,4-D or its removal. Additionally, the enrichment of the sample with 0.5 mM 2,4-D and FA suppressed detection of the gene, suggesting that the two substances may have a synergistic negative effect on ecotoxicity.

Different results were obtained for samples amended with MCPA than those treated with 2,4-D. No PCR products were observed in samples treated with $0.1 \mathrm{mM}$ of MCPA. This might be due to the presence of bacteria which possess other genes responsible for $\mathrm{PH}$ degradation. Previous studies have identified the presence of other RHDO genes in Bradyrhizobium sp., these being the cadA family [31,33]. These amplicons have also been detected in the environment (e.g., activated sludge) [12]. It is important to note that various fungi have also been found to metabolize PHs and to play the sole role in their biodegradation e.g., Streptomyces sp. (isolated from forest soil in Vietnam), Serratia marcescens and Penicillium sp. (isolated from contaminated soil in Brazil) [36]. Therefore, it is possible that the observed absence of bacterial functional genes might be associated with the action of fungi, indeed, the extract used for the experiment would have contained both bacteria and fungi; however, this 
was not investigated in the present study. Nevertheless, fungal strains are known to produce several non-specific enzymes which take part in the degradation of phenolic compounds [37].

Following the addition of SA, increased numbers of bacterial MCPA-degradative genes were detected. Samples spiked with both MCPA and MSM + SE + SA displayed twice the numbers of detected genes than those amended only with MCPA. Such an increase in $t f d A$-like gene numbers suggest that SA can enhance the biodegradation of MCPA, a substance with close structural similarity. As noted above, the samples amended with a higher dose of MCPA demonstrated higher numbers of degradative $t d f A$-like genes; this is also consistent with the results observed for the degradation and mitigation of ecotoxicity of 2,4-D (Table 6). The presence of the $t d f A$-like genes in the soil indicates that of microorganisms capable of degrading MCPA.

These findings confirm those of Bælum et al. (2006) [38], who showed that bacteria harboring $t f d A$ Class III genes were active during the degradation of MCPA; interestingly, they also recorded $t f d A$ Class III and $t f d A \alpha$ in control soil, but not in the MCPA spiked soil samples [38], which is consistent with our previous findings [35]. Similar findings were observed by Poll et al. 2010 [32], who compared the abundance of $t f d A$ and $t f d A \alpha$ in control and MCPA-amended samples. This indicates that the soil was probably enriched in a natural substrate enabling the growth of bacteria harboring the $t f d A \propto$ gene, not necessarily phenoxy acids [31]. The presence of $t f d A$ Class III amplicons in the SA-amended sample indicates that the addition of PSM influences the metabolic properties of the present microbial communities.

By identifying the dominant microorganisms in a sample, it is possible to recognize which bacteria are capable of $\mathrm{PH}$ biodegradation. In order to identify the dominant bacterial strains in samples amended with MCPA and SA, the $16 S$ rRNA sequences were analyzed. The greatest homology (100\%) was achieved with the 16S rRNA gene of Rhodoferax saidenbachensis strain OX0321 (accession number MG576020.1) (Table 5); in addition, the 16S rRNA genes of Achromobacter dolens strain BFHC1 5 (accession number MG897148.1), Burkholderia sp. strain A5 (accession number KY623377.1) and Cupriavidus sp. strain CI099 (accession number MG798754.1) were found to display 99\% homology. These results are consistent with other studies which have revealed the presence of MCPA-degrading strains belonging to the $\beta$-proteobacteria: Rhodoferax sp. [39], Rhodoferax fermentans TFD23, AF049536 [40], Cupriavidus necator JMP134 [41], Cupriavidus sp. [42], Burkholderia sp. [43,44] and Achromobacter sp. [45]. It is also worth noting that microbial communities isolated from rhizosphere soil contaminated with mecocrop (MCPP) differ substantially from those isolated from bulk soil, comprising mainly bacteria belonging to the $\gamma$-Proteobacteria (Pseudomonas spp. and Acinetobacter calcoaceticus) in the presence of MCPP [46].

\subsection{The Influence of Selected PSMs on the Ecotoxicity of 2,4-D/MCPA-Enriched Samples}

Previous studies have examined the ecotoxicity of 2,4-D and MCPA against organisms from various trophic levels. MCPA application was found to increase of soil ecotoxicity towards buckwheat (Fagospyrum esculentum var. Kora), causing stem deformation and discoloration of leaves [47]. Polit et al. [48] demonstrated that MCPA has a toxic effect on seed germination and seedling development of winter oilseed rape (Brassica napus). The application of $1 \mu \mathrm{M}$ and $23 \mathrm{mM} 2,4-\mathrm{D}$ inhibited root/hypocotyl elongation and disturbed mesophyll cell structure in Sinapsis arvensis (wild mustard) and Pisum Sativum (pea), respectively [42,49]. Both, MCPA and 2,4-D, exhibit high toxicity against water organisms, e.g., Microcystis aeruginosa (toxigenic cyanobacteria); Danio rerio (zebrafish); Daphnia magna, Thamnocephalus platyurus, Artemia franciscana (planktonic crustaceans) and Selenastrum capricornutum (green algae), causing severe malformations and cell death [8,9]. Studies by Sarikaya and Yilmaz [50] showed that 2,4-D (66 mg/L) cause internal hemorrhage and behavioral changes in C. carpio. Higher concentrations of 2,4-D caused lysis of human erythrocytes under laboratory conditions [51]. The spread of 2,4-D in the environment can also result in the contamination of water ecosystems, leading to cellular deformation of green algae [52], abnormal cellular proliferation in amphibians (Rhinella arenarum) [53] and the development of non-viable embryos in invertebrates (Biomphalaria glabrata) [54]. 
The present study used an assay based on two dicotyledonous plants (L. sativum and S. alba) to confirm the ecotoxic effect of studied PHs and their mitigation as a result of ongoing physicochemical and biological processes. The ecotoxicity of pure SE at the start of the experiment exceeded the limit of $20 \%$ for both L. sativum (51\%) and S. alba (57\%): as the soil used for the SE preparations was collected from an agricultural field, it is possible that it had been exposed to contaminants prior to collection. After incubation, it was found that although the \% removal of 2,4-D in the studied cases ranged between $83-100 \%$, the ecotoxic effect did not change over time, remaining above the toxicity limit of $20 \%$. Of the two plants used in the assay, L. sativum was more sensitive to the treatment, displaying $100 \%$ root growth inhibition in all samples with 2,4-D, which is consistent with our previous study [35]. This ecotoxicity might have been caused by the formation of 2,4-D metabolites, as the catabolism of 2,4-D leads to the subsequent formation of 2,4-DCP and 3,5-DCC. These intermediates, formed during the degradation processes, have sometimes been found to be more toxic than the original compound [55]. 2,4-DCP has previously been observed to exhibit a strong cytotoxic effect and exert high affinity to the structures of plan cells [56].

The ecotoxicity of 2,4-D was not mitigated by addition of 0.1 or 0.5 mM FA. FA can be excreted to the root rhizosphere in various amounts under stress conditions e.g., when plants are exposed to contaminants that disturb their metabolism [57]. FA also has strong antimicrobial properties [58] and can inhibit seed germination, root and shoot growth and cell division, and exert a negative influence on the physiological parameters of the plants [59]. To conclude, FA was not found to exert a positive effect on ecotoxicity mitigation by increasing the rate of 2,4-D biodegradation, probably due to the formation of metabolites of 2,4-D exhibiting higher toxicity than the original compound. This suggests that both 2,4-D and FA had a toxic effect on the proliferation and catabolic activity of bacterial consortia in the amended samples.

The opposite situation was observed for MCPA: the physicochemical and microbial degradation processes not only reduced the ecotoxicity of the samples but even stimulated the root growth of the test plants. This finding suggests that soil microorganisms introduced to the samples play a major role in the process of herbicide detoxification. Furthermore, although both test plants responded similarly to the initial concentration of $\mathrm{PH}$, higher root growth stimulation was observed for L. sativum after incubation. This is consistent with other studies, where $S$. alba has been found to be more sensitive to MCPA [35].

The above findings indicate that PSM application may have a positive influence on mitigating the ecotoxicity of the samples; however, this influence depends on the selected compounds and concentration of contaminants. In this case, at the higher initial concentration of MCPA used in the study $(0.5 \mathrm{mM})$, higher stimulation of root growth was observed in samples treated with the PSM, i.e., SA $(-55 \%)$ than those which were not $(-47 \%)$.

\section{Conclusions}

The study presents an interdisciplinary approach to the problem of $\mathrm{PH}$ contamination in soil. It focuses not only on the removal rate of the herbicide, but also examines its influence on soil ecotoxicity and the potential for $\mathrm{PH}$ degradation using indigenous soil bacteria. The present findings reveal that measurements of removal percentage can be misleading when estimating ecotoxicity and biodegradation potential. In this case, selected PSMs had different effects on 2,4-D and MCPA biodegradation. Two critical factors were identified for the removal of contaminants and mitigation of the ecotoxicity: the choice of structurally-related phenoxy acid and PSM, and the initial concentration of phenoxy acid. Although the application of the chosen PSM (FA), contributed to the depletion of 2,4-D, a high ecotoxic effect was still observed at the end of incubation. In contrast, SA treatment enhanced the biodegradation of MCPA and encouraged the development of beneficial bacteria harboring a wide array of $t f d A$ - like genes.

This study not only identifies changes in the presence of functional, bacterial degradative genes following PSM application, but also indicates that the two chosen xenobiotics, 2,4-D and MCPA, exert 
different effects on the abundance of degradative potential and ecotoxicity mitigation. The obtained molecular, instrumental and ecotoxicity assessment results demonstrate that the application of PSM can positively influence the removal of structurally-related herbicides; however, the final effect is highly selective and needs further, more elaborate investigation of the molecular mechanisms behind biostimulation processes.

Supplementary Materials: The following are available online at http:/www.mdpi.com/2073-4441/11/7/1451/s1, Table S1: Mean and Standard Deviation for Physical and Chemical Properties of Soil; * Significant Differences at $\alpha \leq 0.05$ According to the Mann-Whitney U-Test, Table S2: Target Genes, PCR Rimers and Their Optimal Annealing Temperature, Figure S1: The Alignment Analysis of 16S rRNA Gene Fragment (1300-1400 bp) Amplified in Samples Enriched with MCPA and Siringic Acid (Query Sequence) and Nucleotide Sequence of Rhodoferax Saidenbachensis OX00321, Figure S2: The Alignment Analysis of 16s rRNA Gene Fragment (1300-1400 bp) Amplified in Samples Enriched with Mcpa and Syringic Acid (Query Sequence) and Nucleotide Sequence of Achromobacter Dolens, Burkholderia sp. Strain a5 and Cupriavidus sp. Strain ci099.

Author Contributions: Conceptualization, M.U., E.M.; methodology, M.U., E.M., M.T., A.B.; validation, M.U., E.M., M.T., A.B..; investigation M.U., E.M.; resources, M.U., E.M.; data curation, M.U., E.M.; writing—original draft preparation, M.U., E.M.; writing-review and editing, M.U., E.M.; visualization, M.U., E.M.; supervision, M.U.; project administration, M.U., E.M.; funding acquisition, M.U., E.M.

Funding: This work was supported by the University of Lodz Student Research Grant "Plant Secondary Metabolites as stimulators of bacterial degradation of 2,4-D and MCPA" and the European Structural and Investment Funds, OP RDE-funded project 'CHEMFELLS4UCTP' (No. CZ.02.2.69/0.0/0.0/17_050/0008485).

Conflicts of Interest: The authors declare no conflict of interest. The funders had no role in the design of the study; in the collection, analyses, or interpretation of data; in the writing of the manuscript, or in the decision to publish the results.

\section{Abbreviations}

The abbreviations with proper definitions used in the study:

PSM plant secondary metabolite

FA ferulic acid

$S A \quad$ syringic acid

PH phenoxy herbicides

2,4-D 2,4-dichlorophenoxy acid

MCPA 2-methyl-4-chlorophenoxyacetic acid

SE $\quad$ soil extract

SSE sterile soil extract

$P R \quad$ percentage removal

$P E \quad$ percentage effect

\section{References}

1. 2008-2012 Market Estimates. Pesticides Industry Sales and Usage; U.S. Environmental Protection Agency: Washington, DC, USA, 2017.

2. Smith, A.E.; Mortensen, K.; Aubin, A.J.; Molloy, M.M. Degradation of MCPA, 2,4-D, and Other Phenoxyalkanoic Acid Herbicides Using an Isolated Soil Bacterium. J. Agric. Food Chem. 1994, 42, 401-405. [CrossRef]

3. Michael, A. Kamrin Phenoxy and Benzoic Acid Herbicides. In Pesticide Profiles, 1st ed.; CRC Press: Boca Raton, FL, USA, 1997; ISBN 978-1-56670-190-7.

4. Skiba, E.; Wolf, W.M. Commercial Phenoxyacetic Herbicides Control Heavy Metal Uptake by wheat in a divergent way than pure active substances alone. Environ. Sci. Eur. 2017, 29, 26. [CrossRef] [PubMed]

5. Eurostat Sales of pesticides by type of pesticide. Available online: https://ec.europa.eu/eurostat/web/productsdatasets/product?code=tai02 (accessed on 11 March 2019).

6. Ignatowicz, K.; Struk-Sokołowska, J. Sezonowe wahania zanieczyszczeń agrotechnicznych w rzece Narwi ze szczególnym uwzględnieniem herbicydów fenoksyoctowych. Środkowo-Pomorskie Tow. Nauk. Ochr. Środowiska. 2004, 4, 189-205. 
7. Ismail, B.S.; Prayitno, S.; Tayeb, M.A. Contamination of rice field water with sulfonylurea and phenoxy herbicides in the Muda Irrigation Scheme, Kedah, Malaysia. Environ. Monit. Assess. 2015, 187, 406. [CrossRef] [PubMed]

8. Li, K.; Wu, J.Q.; Jiang, L.L.; Shen, L.Z.; Li, J.Y.; He, Z.H.; Wei, P.; Lv, Z.; He, M.F. Developmental toxicity of 2,4-dichlorophenoxyacetic acid in zebrafish embryos. Chemosphere. 2017, 171, 40-48. [CrossRef] [PubMed]

9. Caux, P.-Y.; Ménard, L.; Kent, R.A. Comparative study of the effects of MCPA, butylate, atrazine, and cyanazine on Selenastrum capricornutum. Environ. Pollut. 1996, 92, 219-225. [CrossRef]

10. Batogliu-Pazarbasi, M.; Milosevic, N.; Malaguerra, F.; Binning, P.J.; Albrechtsen, H.J.; Bjerg, P.L.; Aamand, J. Discharge of landfill leachate to streambed sediments impacts the mineralization potential of phenoxy acid herbicides depending on the initial abundance of $t f d$ A gene classes. Environ. Pollut. 2013, 176, 275-283. [CrossRef] [PubMed]

11. Mcgowan, C.; Fulthorpe, R.; Wright, A.; Tiedje, J.M.; Gowan, C.M.C. Evidence for Interspecies Gene Transfer in the Evolution of Evidence for Interspecies Gene Transfer in the Evolution of 2,4-Dichlorophenoxyacetic Acid Degraders. Appl. Environ. Microbiol. 1998, 64, 4089-4092.

12. Kitagawa, W.; Kamagata, Y. Diversity of 2,4-Dichlorophenoxyacetic Acid (2,4-D)-Degradative Genes and Degrading Bacteria. In Biodegradative Bacteria: How Bacteria Degrade, Survive, Adapt, and Evolve; Nojiri, H., Fukuda, M., Tsuda, M., Kamagata, Y., Eds.; Springer: Japan, 2014; pp. 43-57. ISBN 978-4-431-54519-4.

13. Musilova, L.; Ridl, J.; Polivkova, M.; Macek, T.; Uhlik, O. Effects of Secondary Plant Metabolites on Microbial Populations: Changes in Community Structure and Metabolic Activity in Contaminated Environments. Int. J. Mol. Sci. 2016, 17, 1205. [CrossRef]

14. Hu, C.; Zhang, Y.; Tang, X.; Luo, W. PCB Biodegradation and bphA1 Gene Expression Induced by Salicylic Acid and Biphenyl with Pseudomonas fluorescence P2W and Ralstonia eutropha H850. Pol. J. Environ. Stud. 2014, 23, 1591-1598.

15. Uhlik, O.; Musilova, L.; Ridl, J.; Hroudova, M.; Vlcek, C.; Koubek, J.; Holeckova, M.; Mackova, M.; Macek, T. Plant secondary metabolite-induced shifts in bacterial community structure and degradative ability in contaminated soil. Appl. Microbiol. Biotechnol. 2013, 97, 9245-9256. [CrossRef] [PubMed]

16. Kruczek, M. Pumpkin (Cucurbita sp.) as a source of health-beneficial compounds with antioxidant properties Dynia (Cucurbita sp.) jako źródło prozdrowotnych związków o charakterze antyoksydacyjnym. Przem. Chem. 2015, 1, 86-90. [CrossRef]

17. Yoon, J.-Y.; Chung, I.-M.; Thiruvengadam, M. Evaluation of phenolic compounds, antioxidant and antimicrobial activities from transgenic hairy root cultures of gherkin (Cucumis anguria L.). South. African, J. Bot. 2015, 100, 80-86. [CrossRef]

18. Suttinun, O.; Lederman, P.B.; Luepromchai, E. Application of terpene-induced cell for enhancing biodegradation of TCE contaminated soil. Songklanakarin, J. Sci. Technol. 2004, 26, 131-142.

19. White, J.C.; Mattina, M.I.; Lee, W.Y.; Eitzer, B.D.; Iannucci-Berger, W. Role of organic acids in enhancing the desorption and uptake of weathered p,p-DDE by Cucurbita pepo. Environ. Pollut. 2003, 124, 71-80. [CrossRef]

20. Yi, H.; Crowley, D.E. Biostimulation of PAH degradation with plants containing high concentrations of linoleic acid. Environ. Sci. Technol. 2007, 41, 4382-4388. [CrossRef] [PubMed]

21. McLoughlin, E.; Rhodes, A.H.; Owen, S.M.; Semple, K.T. Biogenic volatile organic compounds as a potential stimulator for organic contaminant degradation by soil microorganisms. Environ. Pollut. 2009, 157, 86-94. [CrossRef] [PubMed]

22. Zhou, X.; Wu, F. Effects of amendments of ferulic acid on soil microbial communities in the rhizosphere of cucumber (Cucumis sativus L.). Eur. J. Soil Biol. 2012, 50, 191-197. [CrossRef]

23. Modern Water RaPID Assay ${ }^{\circledR}$ 2,4-D. Available online: https://www.modernwater.com/pdf/MW_Factsheet_ Rapid-Assay_2-4-D.pdf (accessed on 11 September 2017).

24. Orphan, V.J.; Sylva, S.P.; Hayes, J.M.; Delong, E.F. Comparative Analysis of Methane-Oxidizing Archaea and Sulfate-Reducing Bacteria in Anoxic Marine Sediments Comparative Analysis of Methane-Oxidizing Archaea and Sulfate-Reducing Bacteria in Anoxic Marine Sediments. Appl. Environ. Microbiol. 2001, 67, 1922-1934. [CrossRef] [PubMed]

25. MicroBioTests Inc. Standard Operational Procedure, Phytotoxkit. Seed Germination and Early Growth Microbiotest with Higher Plants. Available online: https:/www.microbiotests.com/SOPs/Phytotestkit\% 20(complete\%20test)\%20SOP\%20-\%20A5.pdf (accessed on 11 September 2017). 
26. Persoone, G.; Marsalek, B.; Blinova, I.; Törökne, A.; Zarina, D.; Manusadzianas, L.; Nalecz-Jawecki, G.; Tofan, L.; Stepanova, N.; Tothova, L.; et al. A practical and user-friendly toxicity classification system with microbiotests for natural waters and wastewaters. Environ. Toxicol. 2003, 18, 395-402. [CrossRef]

27. Paszko, T.; Muszyński, P.; Materska, M.; Bojanowska, M.; Kostecka, M.; Jackowska, I. Adsorption and degradation of phenoxyalkanoic acid herbicides in soils: A review. Environ. Toxicol. Chem. 2016, 35, 271-286. [CrossRef] [PubMed]

28. Gavrilescu, M. Fate of Pesticides in the Environment and its Bioremediation. Eng. Life Sci. 2005, 5, 497-526. [CrossRef]

29. McMartin, D.W.; Gillies, J.A.; Headley, J.V.; Peterson, H.G. Biodegradation Kinetics of 2,4-Dichlorophenoxyacetic Acid (2,4-D) in South Saskatchewan River Water. Can. Water Resour. J. 2000, 25, 81-92. [CrossRef]

30. Urbaniak, M.; Mierzejewska, E.; Tankiewicz, M. The stimulating role of syringic acid, a plant secondary metabolite, in the microbial degradation of structurally-related herbicide, MCPA. PeerJ 2019, 7, e6745. [CrossRef] [PubMed]

31. Itoh, K.; Tashiro, Y.; Uobe, K.; Kamagata, Y.; Suyama, K.; Yamamoto, H. Root Nodule Bradyrhizobium spp. Harbor tfdA $\alpha$ and cadA, Homologous with Genes Encoding 2,4-Dichlorophenoxyacetic Acid-Degrading Proteins. Appl. Environ. Microbiol. 2004, 70, 2110-2118. [CrossRef] [PubMed]

32. Poll, C.; Pagel, H.; Devers-Lamrani, M.; Martin-Laurent, F.; Ingwersen, J.; Streck, T.; Kandeler, E. Regulation of bacterial and fungal MCPA degradation at the soil-litter interface. Soil Biol. Biochem. 2010, 42, 1879-1887. [CrossRef]

33. Kitagawa, W.; Takami, S.; Miyauchi, K.; Masai, E.; Kamagata, Y.; Tiedje, J.M.; Fukuda, M. Novel 2,4-Dichlorophenoxyacetic Acid Degradation Genes from Oligotrophic. Society 2002, 184, 509-518.

34. Bælum, J.; Jacobsen, C.S.; Holben, W.E. Comparison of $16 S$ rRNA gene phylogeny and functional tfdA gene distribution in thirty-one different 2,4-dichlorophenoxyacetic acid and 4-chloro-2-methylphenoxyacetic acid degraders. Syst. Appl. Microbiol. 2010, 33, 67-70. [CrossRef]

35. Mierzejewska, E.; Baran, A.; Urbaniak, M. The influence of MCPA on soil phytotoxicity and the presence of genes involved in its biodegradation. Arch. Environ. Prot. 2017, 44, 58-64.

36. Silva, T.M.; Stets, M.I.; Mazzetto, A.M.; Andrade, F.D.; Pileggi, S.A.V.; Fávero, P.R.; Cantú, M.D.; Carrilho, E.; Carneiro, P.I.B.; Pileggi, M. Degradation of 2,4-D Herbicide by Microorganisms Isolated from Brazilian Contaminated Soil. Braz. J. Microbiol. 2007, 38, 522-525. [CrossRef]

37. Del Pilar Castillo, M.; Andersson, A.; Ander, P.; Stenström, J.; Torstensson, L. Establishment of the white rot fungus Phanerochaete chrysosporium on unsterile straw in solid substrate fermentation systems intended for degradation of pesticides. World J. Microbiol. Biotechnol. 2001, 17, 627-633. [CrossRef]

38. Bælum, J.; Henriksen, T.; Christian, H.; Hansen, B.; Jacobsen, C.S. Degradation of 4-Chloro-2-Methylphenoxyacetic Acid in Top- and Subsoil Is Quantitatively Linked to the Class III tfdA Gene. Appl. Environ. Microbiol. 2006, 72, 1476-1486. [CrossRef] [PubMed]

39. Ehrig, A.; Müller, R.H.; Babel, W. Isolation of phenoxy herbicide-degrading Rhodoferax species from contaminated building material. Acta Biotechnol. 1997, 17, 351-356. [CrossRef]

40. Lee, T.H.; Kurata, S.; Nakatsu, C.H.; Kamagata, Y. Molecular analysis of bacterial community based on $16 \mathrm{~S}$ rDNA and functional genes in activated sludge enriched with 2,4-dichlorophenoxyacetic acid (2,4-D) under different cultural conditions. Microb. Ecol. 2005, 49, 151-162. [CrossRef] [PubMed]

41. Streber, W.R.; Timmis, K.N.; Zenk, M.H. Analysis, cloning, and high-level expression of 2,4-dichlorophenoxyacetate monooxygenase gene tfdA of Alcaligenes eutrophus JMP134. J. Bacteriol. 1987, 169, 2950-2955. [CrossRef] [PubMed]

42. Pazmiño, D.M.; Rodríguez-Serrano, M.; Romero-Puertas, M.C.; Archilla-Ruiz, A.; del Río, L.A.; Sandalio, L.M. Differential response of young and adult leaves to herbicide 2,4-dichlorophenoxyacetic acid in pea plants: Role of reactive oxygen species. Plant. Cell Environ. 2011, 34, 1874-1889. [CrossRef] [PubMed]

43. Suwa, Y.; Wright, A.D.; Fukumori, F.; Nummy, K.A.; Hausinger, R.P.; Holben, W.E.; Forney, L.J. Characterization of a chromosomally encoded 2,4-dichlorophenoxyacetic acid (2,4-D)/alpha-ketoglutarate dioxygenase from Burkholderia sp. RASC. Appl. Environ. Microbiol. 1996, 62, 2464-2469. [PubMed]

44. Fulthorpe, R.R.; McGowan, C.; Maltseva, O.V.; Holben, W.E.; Tiedje, J.M. 2,4-Dichlorophenoxyacetic acid-degrading bacteria contain mosaics of catabolic genes. Appl. Environ. Microbiol. 1995, 61, 3274-3281. 
45. Xia, Z.Y.; Zhang, L.; Zhao, Y.; Yan, X.; Li, S.P.; Gu, T.; Jiang, J.D. Biodegradation of the Herbicide 2,4-Dichlorophenoxyacetic Acid by a New Isolated Strain of Achromobacter sp. LZ35. Curr. Microbiol. 2017, 74, 193-202. [CrossRef] [PubMed]

46. Lappin, H.M.; Greaves, M.P.; Slatert, J.H. Degradation of the Herbicide Mecoprop [2-(2-Methyl-4-Chlorophenoxy) Propionic Acid ] by a Synergistic Microbial Community. Appl. Environ. Microbiol. 1985, 49, 429-433. [PubMed]

47. Podolska, G. The effectiveness and phytotoxicity of herbicide in buckwheat cv. Kora. Polish, J. Agron. 2014, 19, 17-24.

48. Polit, J.T.; Praczyk, T.; Pernak, J.; Sobiech, Ł.; Jakubiak, E.; Skrzypczak, G. Inhibition of germination and early growth of rape seed (Brassica napus L.) by MCPA in anionic and ester form. Acta Physiol. Plant. 2014, 36, 699-711. [CrossRef]

49. Wei, Y.D.; Zheng, H.G.; Hall, J.C. Role of auxinic herbicide-induced ethylene on hypocotyl elongation and root/hypocotyl radial expansion. Pest. Manag. Sci. 2000, 56, 377-387. [CrossRef]

50. Sarikaya, R.; Yilmaz, M. Investigation of acute toxicity and the effect of 2,4-D (2,4-dichlorophenoxyacetic dichlorophenoxyacetic acid) herbicide on the behavior of the common carp (Cyprinus carpio L., 1758; Pisces, Cyprinidae). Chemosphere 2003, 52, 195-201. [PubMed]

51. Bukowska, B. Effects of 2,4-D and its metabolite 2,4-dichlorophenol on antioxidant enzymes and level of glutathione in human erythrocytes. Comp. Biochem. Physiol. C Toxicol. Pharmacol. 2003, 135, 435-441. [CrossRef]

52. Martínez-Ruiz, E.B.; Martínez-Jerónimo, F. Exposure to the herbicide 2,4-D produces different toxic effects in two different phytoplankters: A green microalga (Ankistrodesmus falcatus) and a toxigenic cyanobacterium (Microcystis aeruginosa). Sci. Total Environ. 2018, 619-620, 1566-1578. [CrossRef] [PubMed]

53. Aronzon, C.M.; Sandoval, M.T.; Herkovits, J.; Pérez-Coll, C.S. Stage-dependent toxicity of 2,4-dichlorophenoxyacetic on the embryonic development of a South American toad, Rhinella arenarum. Environ. Toxicol. 2011, 26, 373-381. [CrossRef] [PubMed]

54. Estevam, E.C.; Nakano, E.; Kawano, T.; de Bragança Pereira, C.A.; Amancio, F.F.; de Albuquerque Melo, A.M.M. Dominant lethal effects of 2,4-D in Biomphalaria glabrata. Mutat. Res. Genet. Toxicol. Environ. Mutagen. 2006, 611, 83-88. [CrossRef] [PubMed]

55. Schweigert, N.; Hunziker, R.; Escher, B.; Eggen, R. Acute toxicity of (chloro-)catechol-copper combinations in Escherichia coil corresponds to their membrane toxicity in vitro. Environ. Toxicol. Chem. 2001, 20, 239-247. [PubMed]

56. Lurquin, P.F. Production of a toxic metabolite in 2,4-D-resistant GM crop plants. 3 Biotech. 2016, 6, 4-7. [CrossRef] [PubMed]

57. Piaia, B.; Alves, C.; Gularte, O.; Teixeira, D.; Cristofari, M.; Ricardo, M.; Carriço, S.; Chimelo, M.; Luiz, R.; Luis, E.; et al. Chemosphere The phytoremediation potential of Plectranthus neochilus on 2,4-dichlorophenoxyacetic acid and the role of antioxidant capacity in herbicide tolerance. Chemosphere 2017, 188, 231-240.

58. Shi, C.; Sun, Y.; Zheng, Z.; Zhang, X.; Song, K.; Jia, Z.; Chen, Y.; Yang, M.; Liu, X.; Dong, R.; et al. Antimicrobial activity of syringic acid against Cronobacter sakazakii and its effect on cell membrane. Food Chem. 2016, 197, 100-106. [CrossRef] [PubMed]

59. Singh, H.P.; Kaur, S.; Batish, D.R.; Kohli, R.K. Ferulic acid impairs rhizogenesis and root growth, and alters associated biochemical changes in mung bean (Vigna radiata) hypocotyls. J. Plant. Interact. 2014, 9, $267-274$. [CrossRef]

(C) 2019 by the authors. Licensee MDPI, Basel, Switzerland. This article is an open access article distributed under the terms and conditions of the Creative Commons Attribution (CC BY) license (http://creativecommons.org/licenses/by/4.0/). 